\section{Ministerial madness avoided}

\section{London}

A TRADE war that would have made a mockery of the forthcoming 'single European market' was averted last week at an emergency meeting of European Communities (EC) agriculture ministers in Brussels, after France, West Germany and Italy dropped their bans on the import of British beef. The bans were introduced on the grounds that public health might be at risk from the bovine spongiform encephalopathy (BSE) epidemic in British cattle - although British agriculture minister John Gummer had accused his European counterparts of acting for economic reasons. British exports of beef to France amount to over $£ 150$ million per year.

In return for the resumption of trade, Gummer had to accept that all exports of British beef carcasses to other member states must come from herds that have been free of BSE for at least two years. This is a climb-down for Gummer, who last year rejected West German calls for a similar 'certification' scheme.

Nevertheless, a spokeswomen for the British agriculture ministry delegation in Brussels said that the agreement was a good one, as trade would be resumed.

The new controls mean that carcasses from about 7,500 herds ( 5 per cent of the UK total) cannot be exported to other member states, unless meat is de-boned and nervous and lymphatic tissues are removed.

The EC agriculture ministers' joint statement also notes that the European Commission is developing surveys to pick up cases of BSE, which was made a notifiable disease in the EC earlier this year. But John Wilesmith, who is leading the UK agriculture ministry's epidemiological work on BSE, says that surveillance in other member states where BSE may become a problem (see below) is less thorough than in the United Kingdom.

The Commission is also reviewing the processes used in manufacture of animal feed across the EC. Britain and the Netherlands have banned the use of ruminant feed containing ruminant protein, thought to be the cause of the BSE outbreak in British cattle, and EC-wide regulations are a possibility in future. But for the time being, the Commission says that animal feed regulations will be left to individual member states. Peter Aldhous

\title{
BSE FRANCE
}

\section{The unexpected export?}

\section{Paris}

FRENCH veterinary experts are worried that their farmers may be sitting on a timebomb. The meal containing ground meat from scrapie-infected sheep, now implicated in the spread of of bovine spongiform encephalopathy (BSE) in Britain, was imported for a short while into France and may trigger an epidemic after the fouryear incubation period is over.

There has even been some speculation, sparked by a report in the British newspaper, The Independent, that cases have already occurred and French farmers are covering them up. The newspaper argues that as BSE has not been officially declared a contagious disease in France, farmers could not claim compensation if BSE cases were found and are thus under pressure to declare them as something else rabies, for example - for which compensation is given.

This is improbable, said Jeanne BrugèrePicoux, head of the bovine pathology department at the Maison d'Alfort Veterinary College near Paris. "I do not think there is much risk of confusion in the clinical diagnosis of rabies and BSE", she said. "A cattle farmer would call a veterinarian if he was worried. He would not make a diagnosis himself".

And cattle suspected of having rabies have, by law, to be sent to the National
Veterinary and Foods Research Centre (CNEVA) at Nancy for post-mortem tests. Jean Blancou, head of the national rabies laboratory at CNEVA said that, since January this year, the brains of cattle that have died with unexplained neurological symptoms, but prove not to be rabid, are sent to Maison d'Alfort for BSE histology. "We have sent 53 brains this year, but none was BSE positive."

But Blancou admits that there are loopholes in the present screening procedures. CNEVA theoretically tests all cattle suspected of rabies. In practice, only farmers from the 40 departments where rabies is endemic send cattle to Nancy for tests.

Although agreeing the system is less than perfect in departments where rabies does not occur, Blancou says that he does not think there have been any cases of BSE. To block the loophole, the Ministry of Agriculture will have ready in a few weeks a decree declaring BSE a recognized disease, so that farmers will receive compensation.

Although no cases of BSE have been reported in France, Brugère-Picoux says there is still a question of whether French cattle have been infected. Since the disease takes over four years to develop, "we will have to wait until 1992 to find out", she said. "We imported British meal, even when Britain banned ruminant-based feed

\section{Terror replaces} debate

\section{London}

IN a disturbing development, two British animal researchers narrowly escaped serious injury last week when their cars were destroyed in separate car bomb attacks. On Wednesday, Margaret Baskerville, a veterinary officer at the Ministry of Defence's chemical defence research establishment at Porton Down, in Wiltshire, was the intended victim. On Sunday, the target was Max Headley, a neurophysiologist from the University of Bristol's physiology department. The Bristol blast partially severed the finger of a 13-month old baby boy, embedding shrapnel in his back.

There is speculation that the attacks could be linked to the explosion which destroyed a bar in the University of Bristol's Senate House administrative building last year - a crime which has remained unsolved. It is thought that a splinter group from the militant Animal Liberation Front (ALF) could be responsible, and a local television company has been contacted by a caller, allegedly an ALF member, who claimed responsibility for the Bristol bombing. Chief inspector Bryan Saunders, from Avon and Somerset police, says detectives are "giving some credence" to the call. ALF's previous activities include assaults on laboratories to 'liberate' experimental animals, and incendiary attacks on department stores selling furs, but its leadership has rejected direct violent action against people.

The attacks have been condemned by police, researchers and animal rights pressure groups. The use of plastic explosives (traces of which were found in the wreckage of Baskerville's car) suggests that the group responsible had intended to kill or maim. The bomb under Headley's car was placed under the front passenger footwell. Police say that any passenger would probably have been killed.

Avon and Somerset police have been accused of complacency over the Bristol bombing. A neighbour spotted a suspicious package under Headley's car on Saturday, and warned the police. Saunders says a check was carried out against records to confirm that the car was owned by a resident of the street in which it was parked, but admits "an officer should have gone to examine the vehicle". Peter Aldhous

for ruminants in 1988." The remaining issue, says Brugère-Picoux, is whether it is safe to eat infected meat. "We do not know the illness well enough to be scared", she said. "But if the risk is small, even negligible, it cannot be ignored. Transmission from cattle to man has not been proved, but it has not been disproved either. We need to be careful and vigilant. I eat beef, but I would not eat calves' brains".

Peter Coles 